\title{
The old order changes
}

It has been a privilege and a pleasure - and (one must admit) an occasional pain - to edit English Today: The International Review of the English Language. The first issue appeared in January 1985, just over two decades ago, and there have been to date just ten short of a century of issues.

Two more remain in my remit, after which, in January 08, a new ET will emerge, and, while it will continue to report on English as a world phenomenon, the approach will be different - and creatively so. In Comment in January 1985, I noted, with regard to getting the first issue out:

'I have developed a fellow feeling for tightrope-walkers and chefs. Certainly, ET's success will depend on keeping one's balance and getting all the ingredients right.... In this issue my main concern has been to cast our net widely enough - to bring in history, geography, statistics, social issues, literature, lexicography, etymology, usage, linguistics, institutions, technological change, and other languages besides English.'

In ET, other languages have always been important: even if it is the most widespread medium the world has ever known, English does not exist in a vacuum, as attested by its mongrel vocabulary. In ET1 (Jan 85) we brought in French, Spanish, Latin, Arabic, Tamil, and Chinese, and subsequent issues have routinely registered, and enlarged on, the interplay between English and the planet's many other systems of speech and writing. To adapt John Donne (1624), 'No language is an island, entire of it self; every one is a piece of the Continent, a part of the main.' ET's next avatar will continue to report on that 'main'.

It is the good fortune of the vast number of native users of English that their language is globally primary, but it is the co-equal good fortune of the vaster number of non-native users that they have, in addition to their own rich lingual heritages, a vade mecum that will serve them almost everywhere they go.

Tom McArthur

The editorial policy of English Today is to provide a focus or forum for all sorts of news and opinion from around the world. The points of view of individual writers are as a consequence their own, and do not reflect the opinion of the editorial board. In addition, wherever feasible, ET generally leaves unchanged the orthography (normally British or American) and the usage of individual contributors, although the editorial style of the journal itself is that of Cambridge University Press.

English Today (ISSN 0266-0784) is published quarterly by Cambridge University Press, The Edinburgh Building, Shaftesbury Road, Cambridge CB2 2RU, UK / Cambridge University Press, 40 West 20th Street, New York, N.Y. 10011-4211.

( ) Cambridge University Press 2007 No contents may be reproduced by any means without the permission of Cambridge University Press.

Subscriptions: The 2007 subscription price (excluding VAT) for four issues for libraries and institutions, which includes print and electronic access, is f98 outside of North America; $f 34$ for individuals; $f 25$ for students and the retired. The electronic-only price available to institutional subscribers is f92. Prices include delivery by air where appropriate. Apply to Jane Crossland at the above address.

Advertising Sales: write to the Advertising Promoter at the above address. Email:

journals_marketing@cambridge.org

USA, CANADA AND MEXICO:

Subscriptions: The 2007 subscription price (excluding VAT) for four issues for libraries and institutions, which includes print and electronic access, is $\$ 163$ in USA, Canada and Mexico; \$54 for individuals; $\$ 39$ for students and the retired. The electronic-only price available to institutional subscribers is $\$ 150$. Apply to Marianne Headrick at Cambridge University Press,

40 West 20th Street, New York, N.Y. 10011-4211.

Advertising Sales: write to the Advertising Coordinator at the above address.

Periodicals postage paid at New York, NY and at additional mailing offices.

POSTMASTER: Send address changes to English Today, Cambridge University Press, 100 Brook Hill Drive, West Nyack, N.Y. 10994-2133.

Japanese prices for institutions are available from Kinokuniya Company Ltd, P.O. Box 55, Chitose, Tokyo 156, Japan.

Contacting the Editor: Email Dr Tom McArthur at <Scotsway@aol.com> or write to him at 22-23 Ventress Farm Court, Cherry Hinton Road, Cambridge CB1 8HD, UK. Tel 01223245934.

Internet access This journal is included in the Cambridge Journals Online service which can be found at http://uk.cambridge.org/journals. For further information on other Press titles access http://uk.cambridge.org.

Designed and typeset by Peter Ducker. Printed in the United Kingdom at the University Press, Cambridge. 